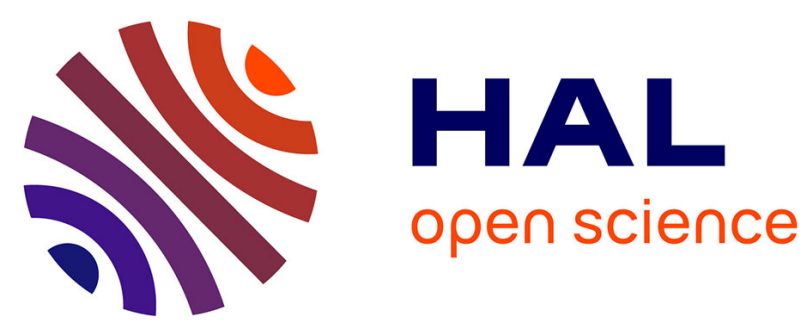

\title{
Effects of GNA and other mannose binding lectins on development and fecundity of the peach-potato aphid Myzus persicae
}

Nicolas Sauvion, Yvan Rahbé, Willy J. Peumans, Els J. M. van Damme, John A Gatehouse, Angharad Gatehouse

\section{To cite this version:}

Nicolas Sauvion, Yvan Rahbé, Willy J. Peumans, Els J. M. van Damme, John A Gatehouse, et al.. Effects of GNA and other mannose binding lectins on development and fecundity of the peachpotato aphid Myzus persicae. Entomologia Experimentalis et Applicata, 1996, 79, pp.285 - 293. hal-02107479

\section{HAL Id: hal-02107479 \\ https://hal.science/hal-02107479}

Submitted on 2 Jul 2019

HAL is a multi-disciplinary open access archive for the deposit and dissemination of scientific research documents, whether they are published or not. The documents may come from teaching and research institutions in France or abroad, or from public or private research centers.
L'archive ouverte pluridisciplinaire HAL, est destinée au dépôt et à la diffusion de documents scientifiques de niveau recherche, publiés ou non, émanant des établissements d'enseignement et de recherche français ou étrangers, des laboratoires publics ou privés. 


\title{
Effects of GNA and other mannose binding lectins on development and fecundity of the peach-potato aphid Myzus persicae
}

\author{
Nicolas Sauvion ${ }^{1}$, Yvan Rahbé ${ }^{1, *}$, Willy J. Peumans ${ }^{2}$, Els J. M. Van Damme ${ }^{2}$, \\ John A. Gatehouse ${ }^{3}$ \& Angharad M. R. Gatehouse ${ }^{3}$ \\ ${ }^{1}$ INSA, Laboratoire de Biologie Appliquée 406, UA INRA 227 - SDI CNRS 5128, 20, ave. A. Einstein, 69621 \\ Villeurbanne, France \\ ${ }^{2}$ Laboratorium voor Phytopathologie en Plantenbescherming, Catholic University of Leuven, 3001 \\ Leuven-Heverlee, Belgium \\ ${ }^{3}$ Department of Biological Sciences, University of Durham, Durham DHI $3 L E, U K$ \\ ${ }^{*}$ Author for correspondence
}

Accepted: November 9, 1995

Key words: Homoptera, Aphididae, lectin, insecticidal

\begin{abstract}
Three mannose-binding lectins were assayed in artificial diets for their toxic and growth-inhibitory effects on nymphal development of the peach-potato aphid Myzus persicae. The snowdrop (Galanthus nivalis) lectin GNA was the most toxic, with an induced nymphal mortality of $42 \%$ at $1500 \mu \mathrm{g} \mathrm{m}^{-1}(30 \mu \mathrm{M})$ and an $\mathrm{IC}_{50}(50 \%$ growth inhibition) of $630 \mu \mathrm{g} \mathrm{ml}^{-1}(13 \mu \mathrm{M})$. The daffodil (Narcissus pseudonarcissus) lectin NPA and a garlic (Allium sativum) lectin ASA induced no significant mortality in the range 10-1500 $\mu \mathrm{g} \mathrm{ml}^{-1}$, but did result in growth inhibition of $59 \%$ (NPA) and $26 \%$ (ASA) at $1500 \mu \mathrm{g} \mathrm{ml}^{-1}$ (40 $\mu \mathrm{M}$ for NPA, $63 \mu \mathrm{M}$ for ASA). All three lectins were responsible for a slight but significant growth stimulation when ingested at $10 \mu \mathrm{g} \mathrm{ml}^{-1}$, reaching $+26 \%,+18 \%$ and $+11 \%$ over the control values for the garlic lectin, the daffodil lectin and the snowdrop lectin, respectively. GNA, as well as the glucose/mannose binding lectin Concanavalin $\mathrm{A}$, were also provided at sublethal doses throughout the life cycle of the aphids, and effects on adult performance were monitored. Adult survival was not significantly altered, but both lectins adversely affected total fecundity and the dynamics of reproduction, resulting in significant reduction in calculated $\mathbf{r}_{m^{\prime} s}$ (population intrinsic rate of natural increase) on lectin-containing diets. These effects are discussed in relation to the use of transgenic plants expressing these toxic lectins for potential control of aphid populations.
\end{abstract}

\section{Introduction}

A large number of secondary compounds, ranging from small molecules to proteins, are toxic to certain insects and have either been demonstrated, or implicated, to be involved in a defensive role (Gatehouse et al., 1990 for review). Amongst these insecticidal proteins are certain lectins (Pratt et al., 1990; Chrispeels \& Raikhel, 1991; Gatehouse et al., 1996) and lectin-like proteins (Osborn et al., 1988; Minney et al., 1990), and although some are known to be toxic to mammals (Pusztai et al., 1979), others are not. Those that fall into the latter category clearly have the potential to be exploited in crop protection via genetic engineering. Examples of these are the lectins from snowdrop (Galanthus nivalis; GNA), daffodil (Narcissus pseudonarcissus; NPA) and garlic (Allium sativum; ASA), and there is evidence to suggest that GNA may even be beneficial to mammals (Pusztai et al., 1993). They are all specific for mannose but differ in their subunit composition, being homotetrameric, homo-trimeric and heterodimeric, respectively. The subunit molecular weight of these proteins is $\approx 12-13 \mathrm{kDa}$ (Van Damme et al., 1988; Pusztai, 1991; Van Damme et al., 1995).

To date most studies concerned with the identification of insecticidal lectins have been limited to 
identifying lectins toxic to members of the Coleoptera (Janzen et al., 1976; Gatehouse et al., 1984; Czapla \& Lang, 1990; Murdock et al., 1990, Gatehouse et al., 1991; Huesing et al., 1991) and Lepidoptera (Shukle \& Murdock, 1983; Czapla \& Lang, 1990; Gatehouse et al., 1992). The first reported demonstration that certain proteins, including some lectins, were toxic to members of the Homoptera was not until 1991, when preliminary results were presented on a Delphacidae (Shi et al., 1991), and shortly after, on an Aphididae (Rahbé \& Febvay, 1992). Powell et al. (1993) tested a series of lectins against the rice brown planthopper (Nilaparvata lugens) and found that the most effective lectins were from snowdrop (GNA) and wheat germ (WGA). Following this demonstration of lectin toxicity towards a homopteran pest and highlighting the possible use of such compounds and other polypeptides in controlling sap sucking insects, several more extensive studies have been carried out (Habibi et al., 1993; Rahbé \& Febvay, 1993; Cole, 1994; Gatehouse et al., 1996).

The objective of the present study was to determine whether certain mannose specific lectins, with no or low mammalian toxicity, were insecticidal to the peach-potato aphid Myzus persicae (Sulz.) with a view to protecting crops from this very important plant pest and virus vector. To this end, the comparative effects of GNA, NPA and ASA on nymphal development and survival were investigated, and also compared to the effect of a glucose-mannose binding lectin (ConA). In addition, fecundity studies on artificial diets containing either GNA or ConA at sublethal doses were carried out over a longer time scale than in previous acute toxicity studies, in order to investigate any effects on the population dynamics of this insect. Data derived from such chronic toxicity studies should provide meaningful information as to the predicted performance on transgenic plants expressing such proteins.

\section{Materials and methods}

Insects. The Myzus persicae clone (LB01) was initially introduced to our laboratory (INRA-Lyon) from a fundatrigeniae clone isolated at INRA Bordeaux on Prunus persica in 1989. The aphids have been reared continuously for at least 2 years on young Vicia faba ( $c v$. Aquadulce) plants under an environmentally controlled condition of $21{ }^{\circ} \mathrm{C}, 60 \%$ r.h., with L16:D8. Mature alate aphids were allowed to settle for $48 \mathrm{~h}$ on plants, and the resulting apterae were grown on $V . f a b a$ seedlings. At sexual maturity, they were put on healthy plants for $24 \mathrm{~h}$ and resulting offspring (aged 0-24 h) used throughout for artificial diet experiments.

Proteins and chemicals. The lectins from GNA, NPA and ASA were purified by affinity chromatography on mannose-agarose and analysed by ion-exchange chromatography as previously described (Van Damme et al., 1991, 1992). The native molecular weights of these lectins were $50 \mathrm{kDa}$ (GNA), $37.5 \mathrm{kDa}$ (NPA) and $24 \mathrm{kDa}$ (ASA), based on their monomer composition (Van Damme et al., 1995). The lectin from Rhizoctonia solani (RSA), specific for $\mathrm{N}$-acetyl galactosamine, was used as a control, and purified by affinity chromatography on gum arabic coupled to Sepharose-6B (Vranken et al., 1987). All proteins were used as saltfree lyophilised powders. ConA was purchased from EY-Lab, ref. L1104 (San Mateo, CA USA).

Artificial diets. A standard diet, diet A5, previously developed for an Acyrthosiphon pisum clone (Febvay et al., 1988) with the exception that the sucrose content was lowered to $20 \%$, was used as the control diet and as the basal diet to which the test proteins were added. This diet supported a first generation growth and development which were comparable to those observed on Vicia plants (mean weight of adults 7 days after eclosion on artificial diet: $\approx 220 \mu \mathrm{g}$, on plants: $\approx 250 \mu \mathrm{g}$ ). Diets containing test proteins (GNA, NPA, ASA, ConA, RSA) were prepared from dilutions of stock protein solutions - in diet - to give a series of 5-fold concentration steps from 10 up to $1500 \mu \mathrm{g}$ $\mathrm{ml}^{-1}$. The diets were sterilised after dilution by filtration through $0.45 \mu \mathrm{m}$ Millipore filters.

Nymphal toxicity tests. Twenty neonate nymphs (aged 0-24 h), obtained from a synchronised population reared on Vicia faba plants, were transferred from bean at day 0 onto sachets containing artificial diets of the different lectins at five different concentrations. Three replicates were carried out for each protein at each concentration, except for the highest concentration, when only two replicates were carried out. One hour after deposition, the percentage of aphids settling on the sachet was noted as an indication of the 'shortterm' phagostimulatory status of the test diet (Rahbé et al., 1988). Sachets were replaced at day 3 or 4 . Mortality was scored on a daily basis and dead insects removed. The aphids were individually weighed at day 8 on an analytical microbalance $\left(10^{-6}\right.$ g precision range; Setaram model Y-214N, Lyon FRA), except for 
winged adults. In our test conditions, the percentage of winged individuals was low $(<10 \%)$.

Fecundity trials. From a synchronised population of M. persicae reared on Vicia faba plants, 60 neonate nymphs (12-14 h) were obtained and placed on each of three artificial diets containing 0,215 and $450 \mu \mathrm{g}$ $\mathrm{ml}^{-1}$ GNA (4.3 and $9 \mu \mathrm{M}$ ). An independent experiment was carried out similarly with ConA at $140 \mu \mathrm{g}$ $\mathrm{ml}^{-1}(1.3 \mu \mathrm{M})$. These concentration values were determined from the toxicity experiments and aimed to induce low nymphal mortality and low but significant growth inhibitions (between theoretical $\mathrm{IC}_{20}$ and $\mathrm{IC}_{40}$ ). After completion of the nymphal period on these diets, mortality was scored, 20 individuals were selected at random (but avoiding those noticeably smaller within a given treatment), weighed and placed individually in cages with diet (control, $215 \mu \mathrm{g} \mathrm{ml}^{-1}$ or $450 \mu \mathrm{g} \mathrm{ml}^{-1}$ for GNA, $140 \mu \mathrm{g} \mathrm{ml}^{-1}$ for ConA). Individual survival and fecundity were recorded daily and the aphids were weighed at day 27 (i.e. after 7 days of nymphal period +20 days adult life; not weighed for ConA).

Data analysis. Survival: Survival rates (\%) were compared at a given time by a standard \% comparison test (hypergeometric law, $n=40$ or 60 ; treatment vs. control).

Growth: Individual weights in $\mathrm{mg}$ were submitted to one-way ANOVA (Analysis of variance) to determine if there was any significant effect of protein concentration on growth, and then analysed with the MacIntosh ${ }^{\circledR}$ non-linear regression package, AjustNonLin (Bonnot \& Febvay, 1992), by fitting the dose/weight data to a Michaelis-Menten model (except for ConA, which fitted better a Log-linear model). The performance on control diet was used as a parameter in this regression (initial weight $=$ mean weight of control), as described earlier (Rahbé \& Febvay, 1993). When growth was stimulated by treatment (as for certain lectins at low doses, see results), the data corresponding to this dose were not included in the growthinhibition curve. Dose effects are given by the concentrations that inhibited nymphal growth by $50 \%\left(\mathrm{IC}_{50}\right)$, as obtained by regressing the computed curves.

Fecundity \& $r_{m}$ : Total fecundities were compared by one-way ANOVA followed by a Bonferroni-Dunn test (Statview 4 and SuperANOVA, Abacus Inc. USA). $r_{m}$ values (nymph/adult/day) were numerically calculated either on individual aphids or on population data, according to the definition given by Birch (1948): $\sum_{i=0}^{\infty} \mathrm{e}^{-r m . x} \cdot l x . m x=1$, where $\mathrm{x}$ is age, $1_{x}$ is agespecific survival and $m_{x}$ age-specific fecundity.

Mean $r_{m}$ values presented in Table 1 are the group values; standard errors were calculated using a jacknife estimator - by successive suppression of one individual from group data - (Miller, 1974); comparisons of means were performed by one-way ANOVA on individual $\mathbf{r}_{m}$ data followed by Bonferroni-Dunn tests.

Fecundity curves were adjusted with AjustNonLin (Bonnot \& Febvay, 1992) to a compartment model described by the equation: $y=p_{3^{2}} \cdot p_{1} \cdot\left(x-p_{2}\right)$. $e^{-p_{3} \cdot\left(x-p_{2}\right)}$ [with $\mathrm{x}>\mathrm{p}_{2}, \mathrm{y}>0$ ], where $\mathrm{y}$ is the daily fecundity per female and $x$ the female age. In this model, $\mathrm{p}_{1}$ represents the modelled total fecundity, $\mathrm{p}_{2}$ the mean pre-reproductive period, and $\mathrm{p}_{3}$ a speed constant of embryo maturation. We used this model to calculate the coordinates of the reproductive peak in Figure 3.

\section{Results}

Effects of mannose-binding lectins on nymphal survival and growth. The effects on nymphal survival of the purified lectins, at different concentrations, were monitored over an eight day period. This period corresponded to normal developmental time to adulthood. The effect of a non-mannose binding lectin, RSA, was followed as a lectin control. No effects on survival at any dose was observed for this particular lectin, and neither were there any effects on growth at doses up to $250 \mu \mathrm{g} \mathrm{ml}^{-1}$ (ANOVA, NS). Only the highest dose $\left(1500 \mu \mathrm{g} \mathrm{ml}^{-1}\right)$ resulted in a significant growth reduction ( $-43 \%, \mathrm{P}<0.05$; data not given).

For all treatments, little effect was seen on nymphal survival over the first few days. By day 3, the highest concentration of GNA $\left(1500 \mu \mathrm{g} \mathrm{ml}^{-1}\right)$ was beginning to significantly affect survival with a reduction of $19 \%$ $(P=0.02)$, and by day 8 survival on this treatment had been further reduced to $58 \%$, whereas on the corresponding control diets after these periods, survival was $88 \%$ (Figure 1). Thus, relative to the control, GNA caused a significant reduction in survival (34\%) during development to adulthood $(\mathrm{P}<0.001)$. None of the other test proteins exhibited any effects upon survival of Myzus persicae.

The effects of the proteins on development were assessed in terms of weight gain over the nymphal period, as compared to controls (Figure 2). All of the mannose specific binding lectins induced significant increase in weight gain at the lowest concentration 
Table 1. Biological performance of Myzus persicae reared on sublethal concentrations of mannose-binding lectins

\begin{tabular}{|c|c|c|c|c|c|c|c|c|}
\hline & \multirow[b]{2}{*}{ Lectin dose } & \multicolumn{3}{|c|}{$\begin{array}{l}\text { Nymphal performance } \\
\text { (day } 7 \text { ) }\end{array}$} & \multicolumn{3}{|c|}{ Adult performance } & \multirow{2}{*}{$\begin{array}{l}\text { Global } \\
\mathrm{r}_{m} \text { (SDjack) }\end{array}$} \\
\hline & & $\begin{array}{l}\text { Nymphal } \\
\text { growth } \\
\mathrm{mg} \pm \mathrm{SE}\end{array}$ & $\begin{array}{l}\text { Nymphal } \\
\text { growth } \\
\text { \% control }\end{array}$ & $\begin{array}{l}\text { Nymphal } \\
\text { mortality } \\
\%\end{array}$ & $\begin{array}{l}\text { Total } \\
\text { fecundity } \\
\text { larv/adult } \pm S E\end{array}$ & $\begin{array}{l}\text { Mortality } \\
\text { at day } 20 \\
\%\end{array}$ & $\begin{array}{l}\text { Weight } \\
\text { at day } 20 \\
\mu \mathrm{g} \pm \mathrm{SE}\end{array}$ & \\
\hline Control & 0 & $221 \pm 7.1 \mathrm{a}$ & 100 & 5 & $18.2 \pm 1.0 \mathrm{a}$ & 5 & $315 \pm 14.7 \mathrm{a}$ & $0.238(0.006) \mathrm{a}$ \\
\hline $\operatorname{Con} A^{* *}$ & 140 & $189 \pm 8.7 b$ & 85 & 21 & $15.1 \pm 1.5 \mathrm{ab}$ & 21 & - & $0.204(0.005) \mathrm{a}$ \\
\hline GNA1 & 215 & $153 \pm 6.8 \mathrm{c}$ & 69 & 12 & $12.7 \pm 0.8 \mathrm{~b}$ & 25 & $236 \pm 9.6 b$ & $0.182(0.004) b$ \\
\hline GNA2 & 450 & $140 \pm 5.4 c$ & 63 & 4 & $11.6 \pm 0.4 b$ & 30 & $218 \pm 10.9 b$ & $0.176(0.003) \mathrm{b}$ \\
\hline
\end{tabular}

$\mathrm{n}=20$, except for nymphal mortality $(\mathrm{n}=100$ ); within a column, values followed by different letters differ significantly at the 5\% level (ANOVA Bonferroni-Dunn tests)

: day 20 is approximatively at half reproductive life; mortality here refers to adult mortality

*: for the ConA independent experiment, control larval weight was $222 \pm 2.4 \mu \mathrm{g}$, control larval mortality was $9 \%$, control fecundity was 18.6 \pm 0.4 and control $\mathrm{rm}$ was $0.222(0.005)$ (values not significantly different from the control in GNA experiment). ANOVAs were carried as for a single experiment.

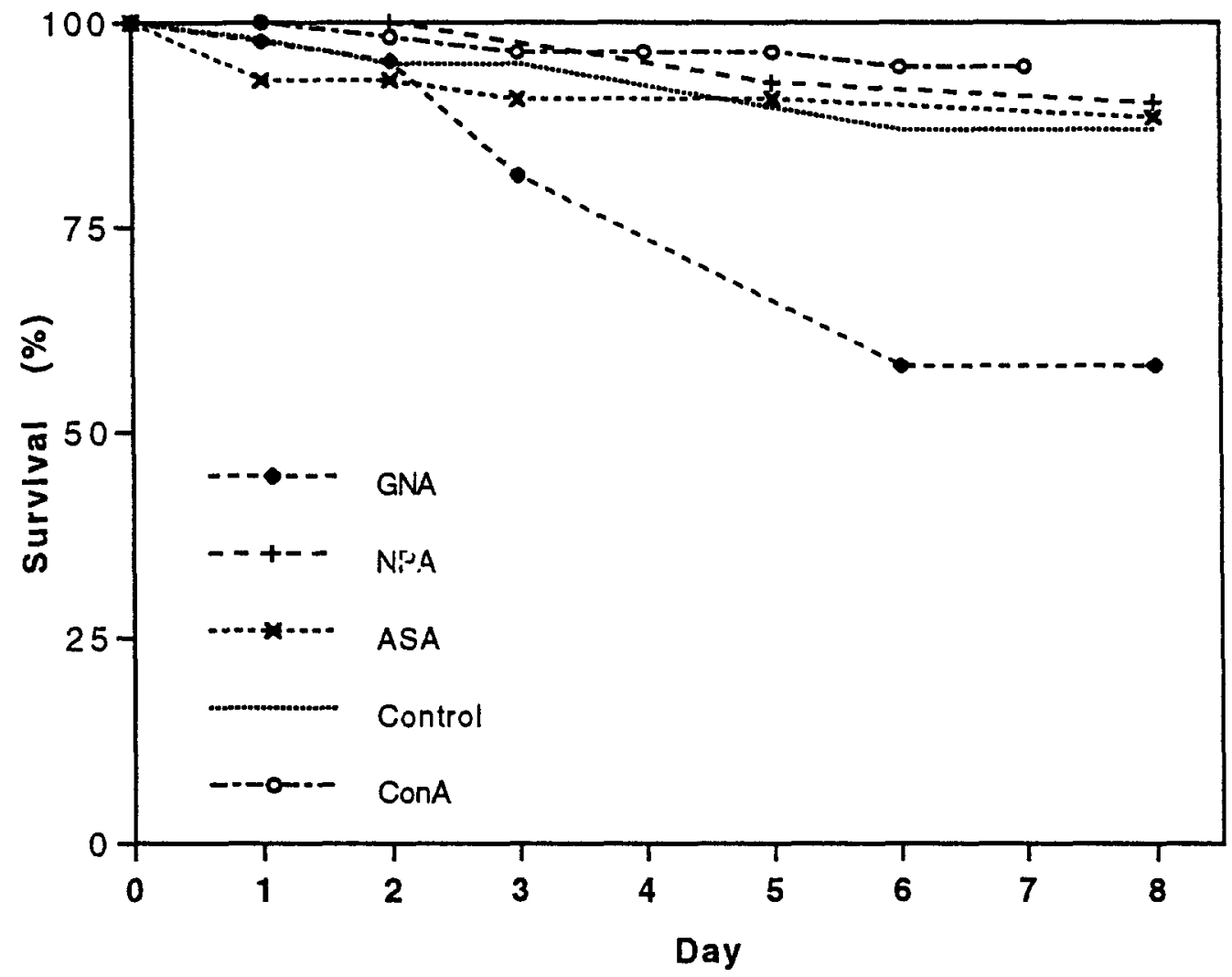

Figure 1. Survival of Myzus persicae nymphs on diets containing $1500 \mu \mathrm{g} \mathrm{ml}^{-1}$ of lectins from snowdrop Galanthus nivalis (GNA), daffodil Narcissus pseudonarcissus (NPA), garlic Allium sativum (ASA), and jackbean Canavalia ensiformis (ConA).

tested $\left(10 \mu \mathrm{g} \mathrm{ml}^{-1}\right.$; ANOVA, significant BonferroniDunn tests over control). This effect was not observed with ConA, either in the present or in previous studies (Rahbe et al., 1995). However, at the higher concentrations, all proteins displayed deleterious effects upon weight gain. Although these effects were statistically significant for all lectins at $250 \mu \mathrm{g} \mathrm{ml}^{-1}$ and more $(\mathrm{P}<0.05)$, ConA and GNA started to exhibit their deleterious effects at a concentration as low as $50 \mu \mathrm{g}$ $\mathrm{ml}^{-1}(\mathrm{P}<0.05)$. With the exception of ASA, which only 
caused significant reduction in weight gain at the highest concentration tested, it was therefore possible to calculate Myzus persicae $\mathrm{IC}_{50}$ values for all the other lectins. Computed $\mathrm{IC}_{50^{\prime} s}$ were 774, 628 and $848 \mu \mathrm{g}$ $\mathrm{ml}^{-1}$ for ConA, GNA and NPA, respectively $(7.3 \mu \mathrm{M}$, $12.5 \mu \mathrm{M}, 23 \mu \mathrm{M}) . \mathrm{IC}_{20}$ values were estimated to be $\approx 10,141,182$ and $478 \mu \mathrm{g} \mathrm{m}^{-1}$ for ConA, GNA, NPA and ASA, respectively $(0.1 \mu \mathrm{M}, 2.8 \mu \mathrm{M}, 4.9 \mu \mathrm{M}$, $20 \mu \mathrm{M})$.

Effect of sublethal concentrations of GNA and ConA on growth and fecundity. Since GNA and ConA showed effects on Myzus growth at the lowest concentrations, the effects of these lectins on fecundity were investigated at sublethal concentrations. One concentration of ConA and two different concentrations of GNA were tested, representing theoretical growth inhibition levels of $\approx 35 \%, \approx 30 \%$ and $\approx 40 \%$ (estimated from the growth inhibition curves). Table 1 summarises the results of nymphal performance in the experiments. These experiments for the two different lectins were not run concurrently, and were therefore carried out with different batches of aphids. Nymphal growth and mortality data show that expected effects were observed for GNA (31\% and $37 \%$ growth reduction) but that the effects observed for ConA were noticeably less than would have been predicted $(-15 \%$ vs. $-35 \%$ expected); controls were very similar in both sets of experiments and all growth inhibition values were significant when compared to control $(\mathrm{P}<0.01)$.

Adult performance is summarised in Table 1 for both lectins, and detailed survival and fecundity curves for GNA are reported in Figure 3 (ConA data are omitted from Figure 3 for clarity, but effects were comparable, although less marked, to those of GNA). Growth of adult insects took place in all treatments, and was proportionally greater for adults which had been reared on the lectin diets $(+62 \%$ and $+56 \%$ for the two concentrations of GNA, $+46 \%$ for aphids on control diet, from onset of maturity to midway through the reproductive period). This result suggests that the lectinmediated growth reduction effect observed during the nymphal stages is less pronounced in the adult stage, allowing a degree of 'catching-up' in development to occur. However, adults on the lectin treatments were still significantly smaller than controls $(75 \%$ and $69 \%$ of control weights for the two concentrations of GNA). Total fecundity was adversely affected by the presence of both lectins $(-19 \%$ for ConA, $-29 \%$ for GNA at $4.3 \mu \mathrm{M},-35 \%$ for GNA at $9 \mu \mathrm{M})$, and the effects on nymphal deposition thus correlated well with the growth inhibition observed in the nymphal stages. The overall impact of dietary lectins on the dynamics of reproduction is reflected by the significant reductions of the $\mathbf{r}_{m}$ parameter (Table 1). It should be noted that the doubling of the GNA levels, although significantly altering the mean levels of growth and overall fecundity, did not result in a significant reduction of the population parameter $r_{m}$ (Table 1). The reduction in $r_{m}$ is also shown on the model fecundity curves presented in Figure 3C, where the presence of lectin altered the dynamics of fecundity by shifting the reproductive peak by more than one day. Whilst shifting the peak, GNA levels did not further modify the shape of this curve.

\section{Discussion}

Although there is good documentation of the insecticidal properties of certain lectins (Gatehouse et al., 1996), it is only in recent years that these studies have been extended to include members of the Homoptera (Habibi et al., 1993; Powell et al., 1993; Rahbé \& Febvay, 1993). More recently, a range of lectins has been assessed for effects on survival and growth towards the pea aphid Acyrthosiphon pisum (Rahbé et al., 1995), and it was those lectins with mannose binding properties that were found to be the most effective. In the present study, the mannose specific lectins ASA, NPA and GNA, and the glucose-mannose specific lectin ConA were each tested at a range of concentrations for their effects upon survival to adulthood, and on development as assessed by weight gain, in the peachpotato aphid, Myzus persicae. Only GNA at the highest concentration had any marked effect upon survival of nymphs to age 8 days, reducing it by $42 \%$, whilst ConA only reduced survival by $5 \%$. These results confirm that polyphagous $M$. persicae is less sensitive to mannose lectin toxicity than the pea aphid (Rahbé et al., 1995), which has a much narrower host range and is confined to members of the Leguminosae. In terms of weight gain all the lectins tested had a significantly adverse effect, particularly at the higher concentrations. Of the mannose specific lectins, GNA (tetramer) had the greatest effect upon weight gain, followed by the trimer NPA and then the dimer ASA. Although these lectins are serologically identical, they differ in the number of subunits per molecule, and thus these results support the hypothesis that their efficacy is determined by the number of subunits per molecule. However, recent reports do suggest fine differences in the sugar recog- 


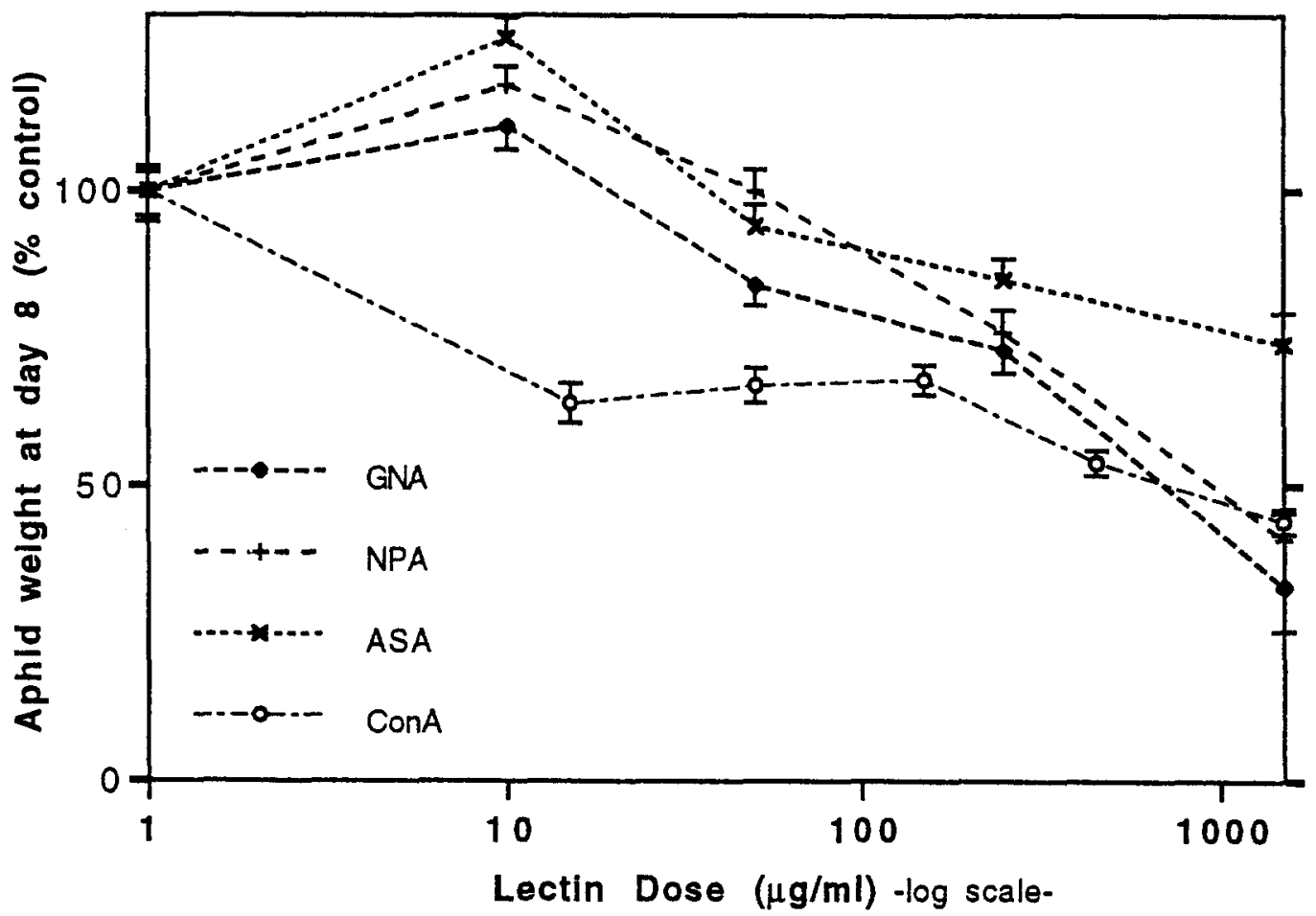

Figure 2. Weight of $M$. persicae after 8 days on diets containing various concentrations of mannose-binding lectins. Aphid weight expressed as \% of control aphids (aphids from same batch reared on standard lectin-free diets). Lectins are as in Figure 1; ConA data are reported for comparison (from Rahbé et al., 1995).

nition properties of NPA and GNA (Kaku et al., 1992) and it may be that the degree of binding affinity to mannose-containing oligosaccharides is a factor which contributes to the observed differences in antimetabolic effect of these related lectins towards $M$. persicae. Similar results for the relative effects of GNA, NPA and ASA have been reported for rice brown planthopper Nilaparvata lugens, where again toxicity was related to subunit number (Powell et al., 1995b).

Of interest is the observation that at the lowest concentration tested all three mannose specific lectins caused a small but significant growth stimulation (with an inverse ranking as for high-dose toxicity; Figure 2). This contrasts to results obtained with ConA at similar levels, where a lectin concentration level of $15 \mu \mathrm{g} \mathrm{ml}^{-1}$ resulted in a growth inhibition of $35 \%$. Similar stimulatory effects caused by lectins at low concentrations have been observed with the cowpea weevil Callosobruchus maculatus (a coleopteran); the effect does not depend on whether a particular lectin is insecticidal or not at higher concentrations (A. Gatehouse, unpublished data). Similar results have also been obtained with mammals, and form the basis of the probiot- ic properties for GNA observed with rats (Pusztai et al., 1990, 1993). It is known that GNA binds to Escherichia coli and in this instance it is thought that it exerts its probiotic effects by mopping-up the bacteria in the gut. This is unlikely to occur within the aphid gut, as many aphids, including $M$. persicae, seem to bear germ free guts (Grenier et al., 1994). The observation that these lectins show a stimulatory effect at low doses has important implications for producing transgenic plants expressing such lectins as a means of controlling aphid populations. Insufficient expression in the phloem could lead to increased rather than decreased aphid population growth. The finding that the mannose specific lectins, and ConA, have different effects at very low concentrations, although they are all toxic at higher concentrations, suggests that they may differ in their modes of action, or may act on different targets within the insect. GNA has both an antifeedant effect and a toxic effect on another homopteran, rice brown planthopper (Powell et al., 1995a).

Since $M$. persicae was less sensitive to GNA than other species, it offered a good model on which to test sublethal effects of GNA ingestion on adult sur- 


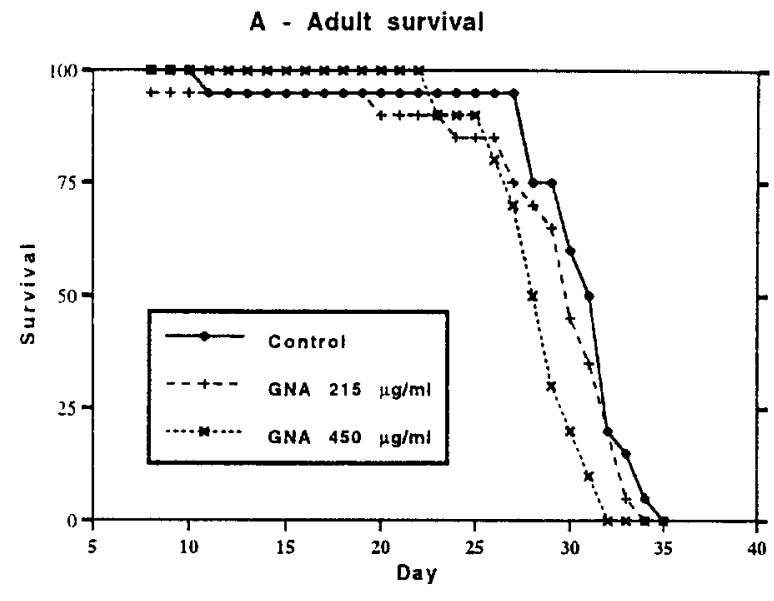

B - Fecundity of adults

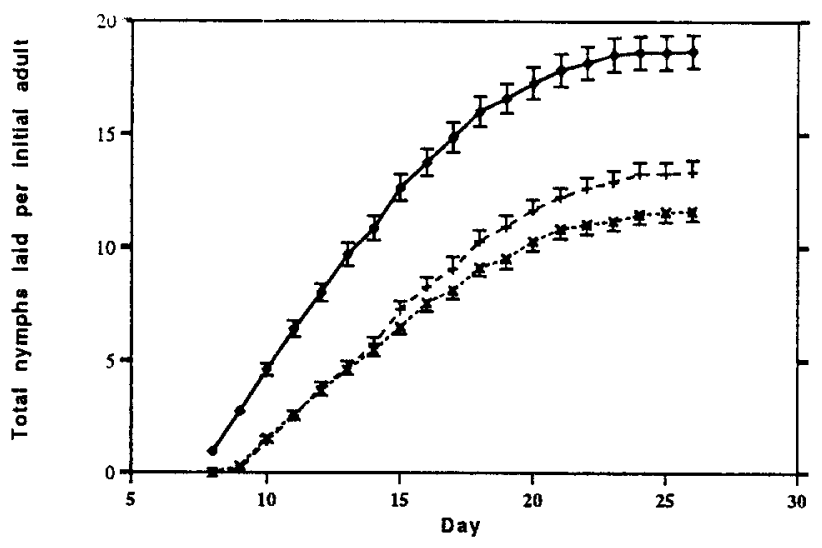

C - Model fecundity curves

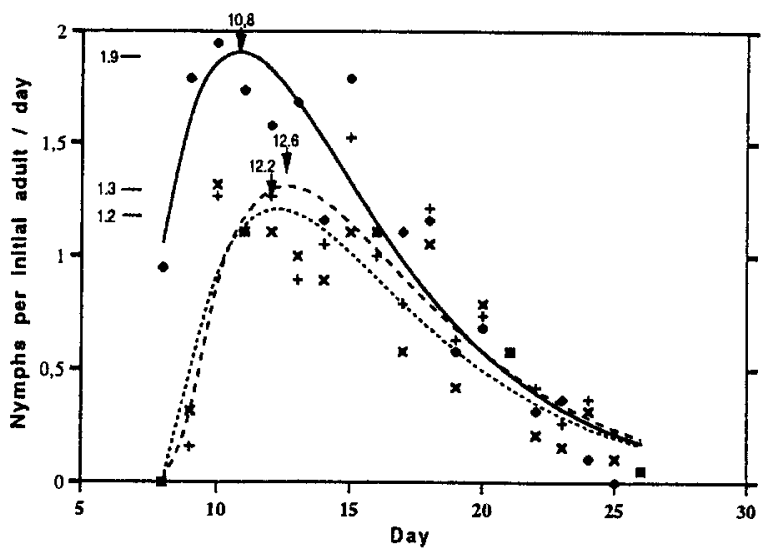

Figure 3. Adult performance (survival and fecundity) of $M$. persicae reared from birth on artificial diets containing 0,215 or $450 \mu \mathrm{g}$ $\mathrm{ml}^{-1}$ of snowdrop lectin (GNA). (A) Adult survival; (B) Cumulative fecundity of surviving aduits (mean $\pm \mathrm{SE}$ ); (C) Model curves for net adult fecundity (model used: see Materials and methods). vival and reproduction. Reduction in fecundity and alteration of reproduction dynamics $\left(\mathrm{r}_{m}\right)$ was observed on all GNA and ConA containing diets, although the effects with ConA were weaker than expected. Variability of effects with ConA has been observed in previous studies with $A$. pisum (Rahbé et al., 1995), and may be a consequence of different batches of protein being used for the nymphal toxicity and fecundity trials. If the significant levels of depression in fecundity obtained in artificial diet studies reflect effects in transgenic plants expressing GNA, then even small variations in $r_{m}$ could change the resistance status of the host plant. For example, on the basis of results obtained in the fecundity assay described above, over a 30-day period the population increase on control plants would have been potentially over 1200 -fold $\left(r_{m}=0.238\right)$, but on transgenic plants expressing GNA at $450 \mu \mathrm{g} \mathrm{ml}^{-1}$ $(9.4 \mu \mathrm{M})$ in the phloem, the corresponding population increase over the same time period would only have reached 200 -fold $\left(r_{m}=0.176\right)$. This theoretical calculation depends on the assumption that the difference in $r_{m}$ is maintained over a longer time-period than that used in the bioassays described. Nevertheless, it illustrates the potential of lectins in pest control, and shows how a significant effect can be produced on population build-up by only a small effect on the reproductive process, as noted by Murdock et al. (1990) for the cowpea weevil. Such a strategy would avoid the strong selective pressures for insect resistance to toxins which cause high levels of mortality. The next step needed for assessing the feasability of transgenic protection to aphids through lectins relies on the intensity of phloem specific expression. The first data with $M$. persicae on transgenic potatoes are encouraging in that, in spite of the use of a non-phloem specific promotor, the plants were readily expressing GNA in the phloem and the effects on fecundity were very similar to those described here on artificial diets (Gatehouse et al., 1995). However, other problems are likely to occur in field trials, especially regarding the effects of aphids on crop yields not directly related to population outbreaks, such as virus transmission. It is actually unlikely that a phloem lectin expression might prevent in any way the spread of non-persistant viruses, and its effect on persistant virus transmission is essentially unpredictable, and should depend on the quite specific gut/lectin interactions, which are currently under investigation. 


\section{Acknowledgments}

\section{A British/French Alliance Scheme travel grant to Yvan Rahbé, Nicolas Sauvion and Angharad Gatehouse is acknowledged. Grant from French Government (MRE) to Nicolas Sauvion is acknowledged. Finan- cial support from Axis Genetics Ltd. and British DTI (AMRG) is gratefully acknowledged. We thank Guy Bonnot for his advice in the modelling of fecundity data.}

\section{References}

Birch, L. C., 1948. The intrinsic rate of natural increase of an insect population. Journal of Animal Ecology 17: 15-16.

Bonnot, G. \& G. Febvay, 1992. AjustNonLin, un logiciel d'ajustement non linéaire sur Mac. Micro Bulletin 44: 101-108.

Chrispeels, M. J. \& N. V. Raikhel, 1991. Lectins, lectin genes, and their role in plant defense. Plant Cell 3: 1-9.

Cole, R., 1994. Isolation of a chitin-binding lectin, with insecticidal activity in chemically defined synthetic diets, from two wild Brassica species with resistance to cabbage aphid Brevicoryne brassicae. Entomologia Experimentalis et Applicata 72: 181187.

Czapla, T. H. \& B. A. Lang, 1990. Effect of plant lectins on the larval development of European Corn Borer (Lepidoptera, Pyralidae) and Southern Corn Rootworm (Coleoptera, Chrysomelidae). Journal of Economic Entomology 83: 2480-2485.

Febvay, G., B. Delobel \& Y. Rahbé, 1988. Influence of the amino acid balance on the improvement of an artificial diet for a biotype of Acyrthosiphon pisum (Homoptera: Aphididae). Canadian Journal of Zoology 66: 2449-2453.

Gatehouse, A. M. R., F. M. Dewey, J. Dove, K. A. Fenton \& A. Pusztai, 1984. Effect of seed lectins from Phaseolus vulgaris on the development of the larvae of Callosobruchus maculatus: mechanism of toxicity. Journal of the Science of Food and Agriculture 35: 373-380.

Gatehouse, A. M. R., V. A. Hilder, K. S. Powell, D. Boulter \& J. A. Gatehouse, 1992. Potential of plant-derived genes in the genetic manipulation of crops for insect resistance. In: S. B. J. Menken, J. H. Visser \& P. Harrewijn (eds), Proc. 8th Int. Symp. Insect-Plant Relationships. Kluwer Acad. Publ., Dordrecht: 221-234.

Gatehouse, A. M. R., D. S. Howe, J. E. Flemming, V. A. Hilder \& J. A. Gatehouse, 1991. Biochemical basis of insect resistance in winged bean (Psophocarpus tetragonolobus) seeds. Journal of the Science of Food and Agriculture 55: 63-74.

Gatehouse, A. M. R., B. H. P. Minney, P. Dobie \& V. A. Hilder, 1990. Biochemical resistance to bruchid attack in legume seeds; investigation and exploitation. In: K. Fujii, A. M. R. Gatehouse, C. D. Johnson, R. Mitchel \& T. Yoshida (eds), Bruchids and Legumes: Economics, Ecology and Coevolution. Kluwer Acad. Publ., (NDL), pp. 241-256.

Gatehouse, A. M. R., K. S. Powell, E. J. M. Van Damme, W. J. Peumans \& J. A. Gatehouse, 1995. Insecticidal properties of plant lectins: their potential in plant protection. In: A. J. Pusztai \& S. Bardocz (eds), Lectins, Biomedical Perspectives. Francis and Taylor, London: $35-57$.
Gatehouse, A. M. R., R. Down, K. S. Powell, N. Sauvion, Y. Rahbe, A. Merryweather \& J. A. Gatehouse, 1996. Transgenic potato plants with enhanced resistance to the peach-potato aphid Myzus persicae. Entomologia Experimentalis et Applicata 79: 295-307.

Grenier, A. M., C. Nardon \& Y. Rahbé, 1994. Observations on the micro-organisms occurring in the gut of the pea aphid Acyrthosiphon pisum. Entomologia Experimentalis et Applicata 70: 91-96.

Habibi, J., E. A. Backus \& T. H. Czapla, 1993. Plant lectins affect survival of the potato leafhopper (Homoptera, Cicadellidae). Journal of Economic Entomology 86: 945-951.

Huesing, J. E., L. L. Murdock \& R. E. Shade, 1991. Effect of wheat germ isolectins on development of Cowpea weevil. Phytochemistry $30: 785-788$.

Janzen, D. H., H. B. Juster \& I. R. Liener, 1976. Insecticidal action of the phytohemagglutinin in black beans on a Bruchid beetle. Science 192: 795-796.

Kaku, H., I. J. Goldstein, E. J. M. Van Damme \& W. J. Peumans, 1992. New mannose-specific lectins from Garlic (Allium sativum) and Ramsons (Allium ursinum) bulbs. Carbohydrate Research 229: 347-353.

Miller, R. G., 1974. The jacknife - a review. Biometrika 61: 1-15.

Minney, B. H. P., A. M. R. Gatehouse, P. Dobie, J. Dendy, C. Cardona \& J. A. Gatehouse, 1990. Biochemical bases of seed resistance to Zabrotes subfasciatus (Bean Weevil) in Phaseolus vulgaris (Common Bean) - A mechanism for Arcelin toxicity. Journal of Insect Physiology 36: 757.

Murdock, L. L., J. E. Huesing, S. S. Nielsen, R. C. Pratt \& R. E. Shade, 1990. Biological effects of plant lectins on the Cowpea weevil. Phytochemistry 29: 85-89.

Osborn, T. C., D. C. Alexander, S. S. Sun, C. Cardona \& F. A. Bliss, 1988. Insecticidal activity and lectin homology of arcelin seed protein. Science 240: 207-210.

Powell, K. S., A. M. R. Gatehouse, V. A. Hilder \& J. A. Gatehouse, 1993. Antimetabolic effects of plants lectins and plant and fungal enzymes on the nymphal stages of two important rice pests, Nilaparvata lugens and Nephotettix cincticeps. Entomologia Experimentalis et Applicata 66: 119-126.

Powell, K. S., A. M. R. Gatehouse, V. A. Hilder \& J. A. Gatehouse, 1995a. Antifeedant effects of plant lectins and an enzyme on the adult stage of the rice brown planthopper, Nilaparvata lugens. Entomologia Experimentalis et Applicata 75: 51-59.

Powell, K. S., A. M. R. Gatehouse, V. A. Hilder, E. L. M. Van Damme, W. J. Peumans, J. Boonjawat, K. Horsham \& J. A. Gatehouse, 1995b. Different antimetabolic effects of related lectins towards nymphal stages of Nilaparvata lugens. Entomologia Experimentalis et Applicata 75: 61-65.

Pratt, R. C., N. K. Singh, R. E. Shade, L. L. Murdock \& R. A. Bressan, 1990. Isolation and partial characterization of a seed lectin from tepary bean that delays bruchid beetle development. Plant Physiology 93: 1453-1459.

Pusztai, A., 1991. Plant lectins. Chemistry and Pharmacology of Natural Products. Cambridge University Press, Cambridge (GBR).

Pusztai, A., E. M. W. Clarke \& T. P. King, 1979. The nutritional toxicity of Phaseolus vulgaris lectins. Proceedings of the nutritional Society 38: $115-120$.

Pusztai, A, S. W. B. Ewen, G. Grant, W. J. Peumans, E. J. M. Van Damme, L. Rubio \& S. Bardocz, 1990. The relationships between survival and binding of plant lectins during small intestinal passage and their effectiveness as growth factors. Digestion 46 (suppl. 2): 308-316.

Pusztai, A., G. Grant, R. J. Spencer, T. J. Duguid, T. S. Brown, S. W. B. Ewen, W. J. Peumans, E. J. M. Van Damme \& S. Bardocz, 1993. Kidney bean lectin-induced Escherichia coli overgrowth in 
the small intestine is blocked by GNA, a mannose-specific lectin. Journal of Applied Bacteriology 75: 360-368.

Rahbé, Y. \& G. Febvay, 1992. Effect of certain proteins on Acyrthosiphon pisum growth and development. Potential influence on Insect-Plant relationships. In: A. K. Minks (eds), 8th International Symposium on Insect-Plant relationships. Wageningen (NDL) 9-13/03/1992: 301-303.

Rahbe, Y. \& G. Febvay, 1993. Protein toxicity to aphids: an in vitro test on Acyrthosiphon pisum (Homoptera: Aphididae). Entomologia Experimentalis et Applicata 67: 149-160.

Rahbé, Y., G. Febvay, B. Delobel \& R. Bournoville, 1988. Acyrthosiphon pisum performance in response to the sugar and amino acid composition of artificial diets, and its relation to lucerne varietal resistance. Entomologia Experimentalis et Applicata 48: 283-292.

Rahbé, Y., N. Sauvion, G. Febvay, W. J. Peumans \& A. M. R. Gatehouse, 1995. Toxicity of lectins and processing of ingested proteins in the pea aphid Acyrthosiphon pisum. Entomologia Experimentalis et Applicata 76: 143-155.

Shi, Y., K. S. Powell, M. B. Wang, V. A. Hilder, A. M. R. Gatehouse, J. A. Gatehouse \& D. Boulter, 1991. Genetically engineered rice resistance to the brown planthopper. Abstr. 5th annu. meeting Int. Prog. Rice Biotechnology, USA.
Shukle, R. H. \& L. L. Murdock, 1983. Lipoxygenase, trypsin inhibitor and lectin from soybean, effects on larval growth of Manduca sexta (Lepidoptera-Sphingidae). Environmental Entomology 12: 787-791.

Van Damme, E. J. M., A. K. Allen \& W. J. Peumans, 1988. Related mannose-specific lectins from different species from the family Amaryllidaceae. Physiologia Plantarum 73: 52-57.

Van Damme, E. J. M., K. Smeets \& W. J. Peumans, 1995. The mannose binding monocot lectins and their genes. In: A. Pusztai \& S. Bardocz (eds), Lectins: Biomedical Perspectives. Taylor \& Francis, London: 59-90.

Van Damme, E. J. M., K. Smeets, S. Torrekens, F. Vanleuven, I. J. Goldstein \& W. J. Peumans, 1992. The closely related homomeric and heterodimeric mannose-binding lectins from garlic are encoded by one-domain and 2-domain lectin genes, respectively. European Journal of Biochemistry 206: 413-420.

Van Damme, E. L. M., I. J. Goldstein \& W. J. Peumans, 1991. A comparative study of mannose beinding lectins from the Amaryllidaceae and Alliaceae. Phytochemistry $30: 509-514$.

Vranken, A. N., E. J. M. Van Damme, A. K. Allen \& W. J. Peumans, 1987. Purification and properties of an $\mathrm{N}$-acetyl galactosamine specific lectin from the plant pathogenic fungus $R h i$ zoctonia solani. FEBS Letters 216: 67-72. 